DOI: https://doi.org/10.24127/ajpm.v9i4.3157

\title{
PENGEMBANGAN LEMBAR KERJA PESERTA DIDIK BERBASIS HIGH ORDER THINKING SKILLS PADA MATERI HIMPUNAN
}

\author{
Gunawan $^{1 *}$, Erni Widiyastuti², Salma Nur Azizah ${ }^{3}$ \\ ${ }^{1 * 2,3}$ Pendidikan Matematika, Universitas Muhammadiyah Purwokerto, Indonesia \\ *Corresponding author \\ E-mail: $\quad$ gun.oge@gmail.com ${ }^{1 *}$ \\ erniwidiya26@gmail.com $^{2)}$ \\ salmanur@ump.ac.id ${ }^{3)}$
}

Received 12 October 2020; Received in revised form 05 December 2020; Accepted 12 December 2020

\begin{abstract}
Abstrak
Penelitian ini menghasilkan Lembar Kerja Peserta Didik (LKPD) Matematika bermuatan HOTS. Proses pengembangan LKPD ini menggunakan model-4D yang dikemukakan oleh Thiagarajan yang terdiri dari 4 tahap yaitu pendefinisian, desain, pengembangan, dan uji produk. Subyek yang digunakan adalah siswa kelas VIII SMP Negeri 2 Karanglewas.Teknik pengumpulan data meliputi angket hasil validasi dan kepraktisan. Analisis data yang dipakai meliputi data kualitatif dan kuantitatif. Hasil uji validasi LKPD dari ketiga validator diperoleh skor rata-rata 3,13 yang menunjukkan LKPD valid. Hasil uji kepraktisan LKPD diperoleh rata-rata 3,01 yang berarti praktis. Dengan demikian, LKPD berbasis HOTS materi Himpunan valid dan praktis serta dapat digunakan dalam kegiatan pembelajaran.
\end{abstract}

Kata kunci: high order thinking skills (HOTS); himpunan; LKPD

\begin{abstract}
This research produce Mathematics Student Worksheets containing High Order Thinking Skills (HOTS). The process of Student Worksheets development was conducted using the 4D model proposed by Thiagaradjan consisted of 4 stages, namely the stage of define, design, develop, and disseminate. The subjects used were grade VIII students of SMP Negeri 2 Karanglewas. The data technique used was a questionnaire of validation results and practicality. The data analysis used includes qualitative and quantitative data. The Student Worksheets validation test results from the three validators obtained an average score of 3.13 which indicates a valid. LKPD practicality test results obtained an average of 3.01 which means practical. Thus, the student worksheets based HOTS of set material is valid and practical and can be used in learning activities.
\end{abstract}

Keywords: high order thinking skills (HOTS); set; LKPD

This is an open access article under the Creative Commons Attribution 4.0 International License

\section{PENDAHULUAN}

Pada zaman serba canggih seperti sekarang ini, terjadi perubahan yang sangat cepat akan tetapi ada hal yang masih memiliki peran pokok dalam kehidupan yaitu pendidikan. Beberapa faktor yang mempengaruhi kesuksesan dalam pendidikan diantaranya evaluasi dan hasil belajar (Noprinda \& Soleh, 2019). Dalam pendidikan, ada tiga kompetensi yang diperoleh yaitu pengetahuan, sikap, dan keterampilan. Kegiatan mengingat, memahami, menerapkan, menganalisis, mengevaluasi, dan mencipta merupakan cara memperoleh kompetensi pengetahuan. Berkaitan dengan hal tersebut, salah satu kemampuan yang harus dimiliki adalah kemampuan berfikir tingkat tinggi (High Order Thinking Skills). 
Perilaku menerima, menjalankan, menghargai, menghayati, dan mengamalkan untuk memperoleh kompetensi sikap. Sedangkan, keterampilan diperoleh serangkaian menalar, menyaji, dan mencipta. Dengan berbagai kegiatan tersebut, siswa dapat mengasah kembali kemampuan berfikir tingkat rendah menjadi berfikir tingkat tinggi. Kemampuan seseorang dalam mengkombinasikan seluruh pengetahu-an yang dimiliki secara kritis dan kreatif dalam memecahkan persoalan disebut berpikir tingkat tinggi (Winarni, 2019).

Indonesia salah satu negara yang kurang menerapkan kemampuan berfikir tingkat tinggi siswa. Berdasarkan hasil PISA, di tahun 2015 Indonesia menempati urutan 62 dari 70 negara. Sedangkan, peringkat 71 dari 78 di tahun 2018 sehingga membuat Indonesia berada satu tingkat lebih rendah dari Filipina (OECD, 2019). PISA adalah program yang dibuat oleh Organitation of Economic Co-operation and Development (OECD) untuk mengevaluasi sistem pendidikan negara seluruh dunia rutin setiap 3 tahun. Bahan yang dievaluasi adalah sains, membaca, dan matematika. Dalam PISA, soal yang dibuat kontekstual dengan kehidupan sehari-hari kemudian siswa diarahkan untuk menyelesaikannya menggunakan pengetahuan yang dimiliki (Kurniati, Harimukti, \& Jamil, 2016). Soal tersebut terdiri dari 6 level diantaranya memuat level 4,5,6 yang merupakan level pada kemampuan tingkat tinggi. Pada teori taksonomi bloom, level high order thinking skills (HOTS) terdiri atas menganalisis, mengevaluasi, dan mencipta (Dinni, 2018). Dalam mengerjakan soal PISA, siswa diarahkan untuk menalar, mengevaluasi, dan mengkreasi (Kurniati, Harimukti, \& Jamil, 2016). Sehingga, dapat disimpulkan bahwa PISA merepresentasikan kemampuan berfikir tingkat tinggi atau high order thinking skills (HOTS). Dalam menyusun soal, level berpikir tingkat tinggi terletak pada level analisis (C4), evaluasi (C5), dan mencipta (C6) (Fanani, 2018).

Dalam pembelajaran, hendaknya mengaplikasikan HOTS. Dengan pembelajaran tersebut, siswa yang memiliki daya pikir tinggi dapat belajar, meningkatkan kinerja, dan mengurangi kelemahannya (Tanujaya, 2016). Faktor lain yang mempengaruhi berfikir tingkat tinggi yaitu motivasi belajar (Rooney, 2012). Dengan motivasi yang baik, siswa dapat meningkatkan hasil belajar Dalam (Tanujaya, B., Mumu, J., \& Margono, 2017) ada hubungan yang positif dan kuat antara berfikir tingkat tinggi dan hasil belajar. Dengan demikian, pembelajaran yang menerapkan berfikir tingkat tinggi dapat membantu siswa memperoleh hasil belajar yang baik.

Guru memiliki peran yang penting terhadap tinggi rendahnya pencapaian PISA di Indonesia. Hal tersebut dicapai apabila secara rutin siswa dilatih untuk berfikir HOTS (Mulyaningsih \& Itaristanti, 2018). Masih banyak sekolah yang menerapkan pembelajaran yang berorientasi berfikir level rendah (Pratiwi, 2018). Hal ini diperkuat dari suatu penelitian yang dilakukan oleh (Ichsan, Sigit, Miarsyah, Ali, Arif, \& Prayitno, 2019) di SMP Negeri 1 Surakarta, bahwa penggunaan soal-soal berbasis HOTS baru sedikit diterapkan. Berdasarkan hasil wawancara dengan guru kelas VIII SMP Negeri 2 Karanglewas, dalam pembelajaran sudah menggunakan LKPD hanya saja isinya masih fokus pada kemampuan berfikir tingkat rendah, masalah yang disajikan tidak kontekstual dan berisi soal singkat, dan tampilan/visualisasi masih monoton dalam hal ini kurang 
menarik sehingga siswa cenderung pasif. Sehingga, ketika guru memberikan masalah aplikatif siswa kesulitan untuk memahami dan menyelesaikannya. Hal tersebut menunjukkan bahwa siswa belum terbiasa dan kesulitan dalam menyelesaikan masalah tingkat HOTS.

Kemampuan berfikir tingkat tinggi siswa dapat dilatih dan diukur menggunakan instrumen penilaian yaitu dalam mengerjakan soal siswa dapat memberikan jawaban yang sesuai berdasarkan kemampuan berpikirnya, sehingga guru mengetahui seberapa baik kemampuan berpikir siswa tersebut (Merta Dhewa, Rosidin, Abdurrahman, \& Suyatna, 2017). Agar level berfikir siswa bertambah, guru harus sering melibatkan dalam kegiatan pemecahan masalah yang tidak rutin (Apino, \& Retnawati, 2017). Ada berbagai upaya untuk mengembangkan kemampuan berpikir tingkat tinggi pada siswa, salah satu upaya yang bisa dilakukan adalah menggunakan Lembar Kerja Peserta Didik (LKPD). LKPD merupakan lembaran berisi soal-soal yang dibuat sedemikian rupa sebagai media dalam rangka memperbaiki pembelajaran (Zahrotul,2017). LKPD yang menyajikan masalah HOTS dapat mengembangkan berfikir aktif dan kreatif. Hal tersebut sejalan dengan (Musfiqi \& Jailani, 2014) bahwa untuk mengajak siswa berperan aktif menyelesaikan persoalan matematis secara kritis dan kreatif perlu disajikan masalah HOTS. Karakteristik pembelajaran digunakan sebagai pertimbangan dalam menyusun LKPD (Widjayanti, 2008). Dalam hal ini, kondisi di dalam kelas dan karakteristik siswa. Artinya, kondisi pembelajaran yang tidak aktif, tidak terjalinnya interaksi yang baik antara guru dan siswa, dan siswa terbiasa dengan contoh soal tertentu ketika diberikan soal pengembangan/kontekstual mengalami kesulitan dengan alasan tidak sama dengan yang dicontohkan. Hal ini relevan dengan (Relia, 2016) bahwa LKPD merupakan suatu perangkat pembelajaran yang diharapkan mampu menjembatani interaksi yang baik antara guru dan siswa sehingga terbentuk pembelajaran yang aktif. LKPD Matematika bermuatan HOTS pada materi himpunan kelas VII SMP ini disusun sedemikian sehingga memuat kegiatan-kegiatan yang mengonstruksi pemikiran siswa menemukan suatu definisi dan dilengkapi soal berfikir tingkat tinggi. Berdasarkan uraian di atas, akan dihasilkan LKPD berbasis HOTS yang valid dan praktis untuk digunakan dalam pembelajaran SMP pada materi Himpunan.

\section{METODE PENELITIAN}

Penelitian ini termasuk ke dalam jenis research and development (R\&D). Pada penelitian ini mengembangkan suatu produk berupa LKPD Matematika bermuatan HOTS materi. Subjek pengembangan penelitian ini adalah materi himpunan yang akan disajikan dalam LKPD Matematika bermuatan HOTS untuk siswa kelas VIII SMP Negeri 2 Karanglewas yang diambil sampel sejumlah 9 siswa. Desain penelitian yang digunakan adalah Research and Development 4-D menurut (Thiagarajan, Semmel, \& Semmel, 1974; Trianto, 2010) meliputi yang terdiri dari empat tahap, yaitu: define (definisi), design (desain), develop (pengembangan), dan disseminate (penyebaran). Data diperoleh berdasarkan angket kevalidan dan kepraktisan. Angket validasi ditujukan kepada validator dalam bentuk google form. Teknis analisis data meliputi data kualitatif dan kuantitatif. Data kualitatif terdiri dari saran yang 
diberikan oleh bahan ajar terhadap LKPD yang akan dianalisis secara deskriptif kualitatif. Hasil analisis kemudian menjadi bahan revisi LKPD. Data kuantitatif diperoleh dari jawaban angket validator. Teknik yang digunakan untuk menganalisis data dari hasil validasi adalah perhitungan ratarata. Nilai akhir yang diperoleh adalah nilai rata-rata per indikator dari total nilai jawaban validator. Nilai akhir pada angket dapat diidentifikasi, caranya jumlah nilai dibagi jumlah validator (Arikunto, 2010). Lebih jelasnya, disajikan dalam rumus (1):

Rentang $=\frac{\text { Skor Tertinggi }- \text { Skor Terendah }}{\text { Skor Tertinggi }}$

Pada kriteria ini, skala penilaian yang digunakan adalah 1 sampai 4 , dimana 1 skor terendah dan 4 dkor tertinggi. Berdasarkan rumus tersebut, diperoleh rentang 0,75. Perhatikan Tabel 1.

Tabel 1. Kriteria validasi

\begin{tabular}{cc}
\hline Rata-rata $(\overline{\mathbf{x}})$ & Kriteria \\
& \\
\hline $3,25 \leq \overline{\mathrm{x}} \leq 4,0$ & Sangat Valid \\
$2,5 \leq \overline{\mathrm{x}}<3,25$ & Valid \\
$1,75 \leq \overline{\mathrm{x}}<2,5$ & Kurang Valid \\
$1,0 \leq \overline{\mathrm{x}}<1,75$ & Tidak Valid \\
\hline
\end{tabular}

Sama halnya dengan kriteria kepraktisan, untuk pedoman kepraktisan dapat dilihat pada Tabel 2.

Tabel 2. Kriteria kepraktisan.

\begin{tabular}{cc}
\hline Rata-rata $(\overline{\mathbf{x}})$ & Kriteria \\
& \\
\hline $3,25 \leq \overline{\mathrm{x}} \leq 4,0$ & Sangat Baik \\
$2,5 \leq \overline{\mathrm{x}}<3,25$ & Baik \\
$1,75 \leq \overline{\mathrm{x}}<2,5$ & Kurang Baik \\
$1,0 \leq \overline{\mathrm{x}}<1,75$ & Tidak Baik \\
\hline
\end{tabular}

\section{HASIL DAN PEMBAHASAN}

Penelitian ini menghasilkan Lembar Kerja Peserta Didik (LKPD) Matematika bermuatan HOTS materi Himpunan kelas VIII SMP. Disusun untuk pemahaman siswa, keaktifan, dan ikut berperan dalam mengikuti proses belajar mengajar. Di dalamnya terdapat pertanyaan tuntunan untuk membangun pemikiran siswa menemukan suatu penyelesaian masalah. Selain itu, memuat latihan soal yang melatih kemampuan berpikir tingkat tinggi siswa. Latihan soal tersebut mengacu pada indikator berpikir tingkat tinggi yang telah dirumuskan oleh Bloom, yaitu menganalisis, menilai, dan mengkreasi (Dinni, 2018). Berikut identifikasi perbedaan LKPD yang dibuat dengan produk sebelumnya yang disajikan dalam Tabel 3.

Tabel 3. Perbedaan produk sebelum dengan produk sesudah dikembangkan.

\begin{tabular}{|c|c|c|}
\hline No & $\begin{array}{l}\text { Produk } \\
\text { sebelum } \\
\text { dikembangkan }\end{array}$ & $\begin{array}{l}\text { Produk } \\
\text { sesudah } \\
\text { dikembangkan }\end{array}$ \\
\hline 1 & $\begin{array}{l}\text { Tidak } \\
\text { menggunakan } \\
\text { animasi } \\
\text { berwarna }\end{array}$ & $\begin{array}{l}\text { Menggunakan } \\
\text { animasi } \\
\text { berwarna } \\
\text { dengan aplikasi } \\
\text { Corel Draw }\end{array}$ \\
\hline 2 & $\begin{array}{l}\text { Tidak } \\
\text { menggunakan } \\
\text { teka teki silang } \\
\text { di akhir topik } \\
\text { dan kegiatan }\end{array}$ & $\begin{array}{l}\text { Menggunakan } \\
\text { menu teka teki } \\
\text { silang di akhir } \\
\text { topik } \\
\text { pembelajaran }\end{array}$ \\
\hline 3 & $\begin{array}{l}\text { Soal yang } \\
\text { digunakan } \\
\text { masih } \\
\text { mengukur level } \\
\text { kemampuan } \\
\text { dasar }\end{array}$ & $\begin{array}{l}\text { Soal yang } \\
\text { digunakan } \\
\text { menerapkan } \\
\text { kemampuan } \\
\text { HOTS }\end{array}$ \\
\hline
\end{tabular}

Berikut pembahasan setiap tahap yang digunakan dalam penelitian ini:

1. Tahap Pendefinisian (Define) 
Tahap-tahap yang dilakukan dalam pendefinisian meliputi lima pokok diantaranya analisis awal akhir, analisis siswa, analisis konsep, analisis tugas dan perumusan pembelajaran yang dijelaskan. Salah satu tuntutan kurikulum 2013 adalah peserta didik untuk lebih aktif mengkonstruksi pengetahuannya (Waseso, 2018). Menurut pengakuan guru matematika kelas VIII SMP Negeri 2 Karanglewas melalui wawancara, LKPD yang ada jarang digunakan melainkan hanya digunakan saat evaluasi pembelajaran. Selain itu, soal yang disajikan masih dalam tingkat kemampuan rendah.

2. Tahap Perancangan (Design)

Format yang digunakan pada LKPD ini adalah menggunakan kertas ukuran A4 dengan margin atas dan margin kiri $3 \mathrm{~cm}$, margin kanan $2 \mathrm{~cm}$, dan margin bawah $2 \mathrm{~cm}$, margin atas 2 $\mathrm{cm}$ serta ukuran 1,5 spasi. Pembuatannya menggunakan aplikasi Corel Draw. Halaman depan LKPD dalam Gambar 1.

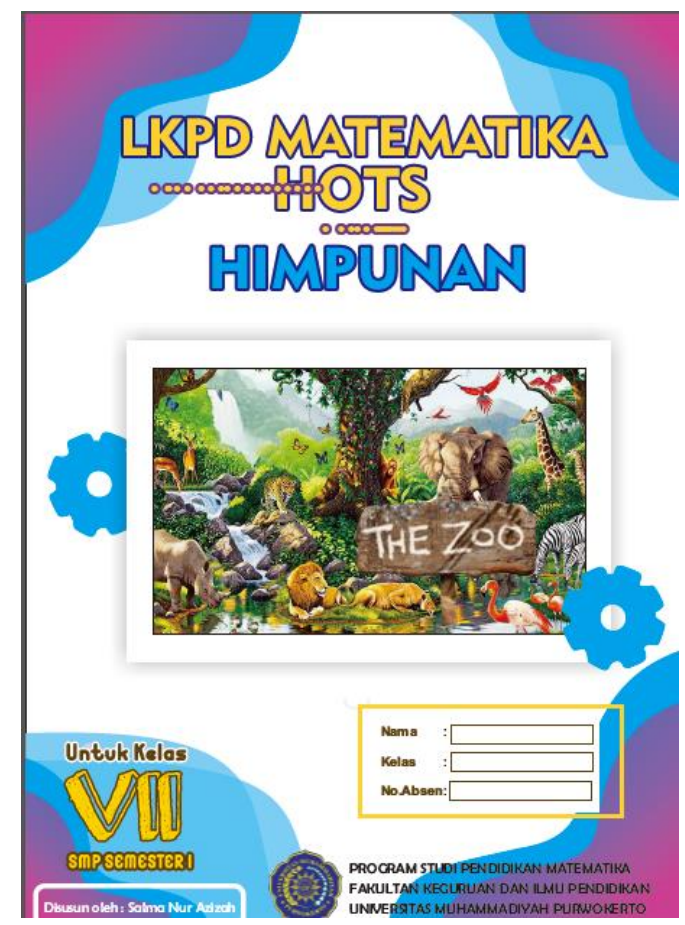

Gambar 1. Desain halaman depan LKPD
LKPD ini terdiri atas beberapa bagian diantaranya judul, cover, kata pengantar, petunjuk penggunaan LKPD, KI dan KD, indikator, kegiatan pembelajaran, latihan soal HOTS, uji kompetensi, dan daftar pustaka. Dapat terlihat pada Gambar 2.

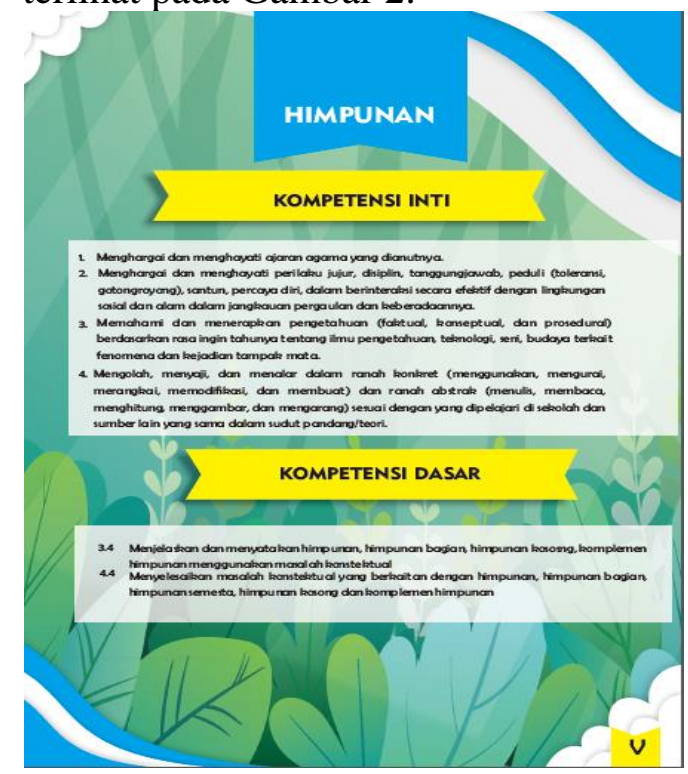

Gambar 2. Tampilan KI dan KD

Terdapat juga peta konsep materi Himpunan. Berisi gambar mengenai sub materi himpunan yang akan dipelajari (Gambar 3).

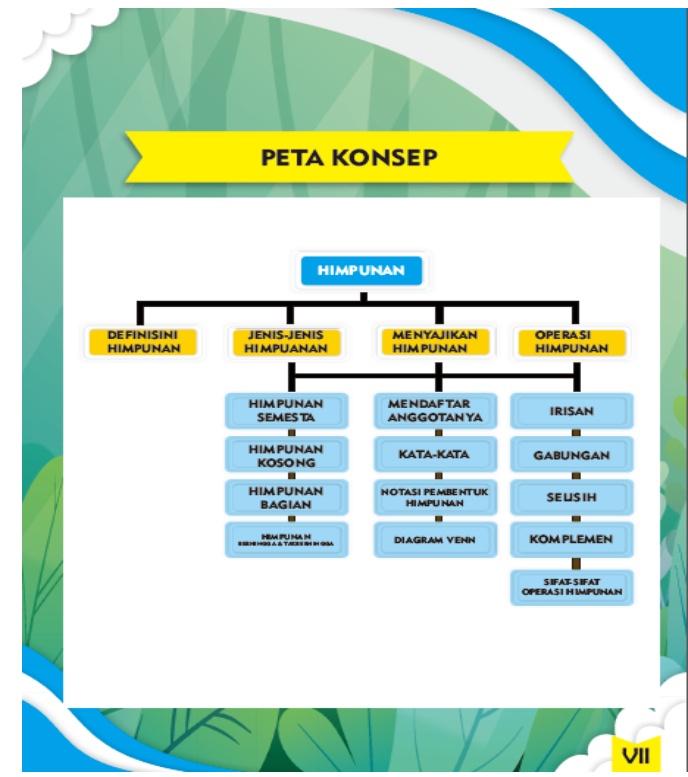

Gambar 3. Peta Konsep Materi Himpunan. 
Soal HOTS yang dipakai dalam LKPD ini adalah level kemampuan menganalisis (C4). Berdasarkan soal, siswa menuliskan himpunan yang mungkin terbentuk berdasarkan uraian cerita yang disajikan dalam hal ini menuliskan menu makanan yang dibeli dengan menyesuaikan harga masingmasing. Dapat dilihat pada Gambar 4.

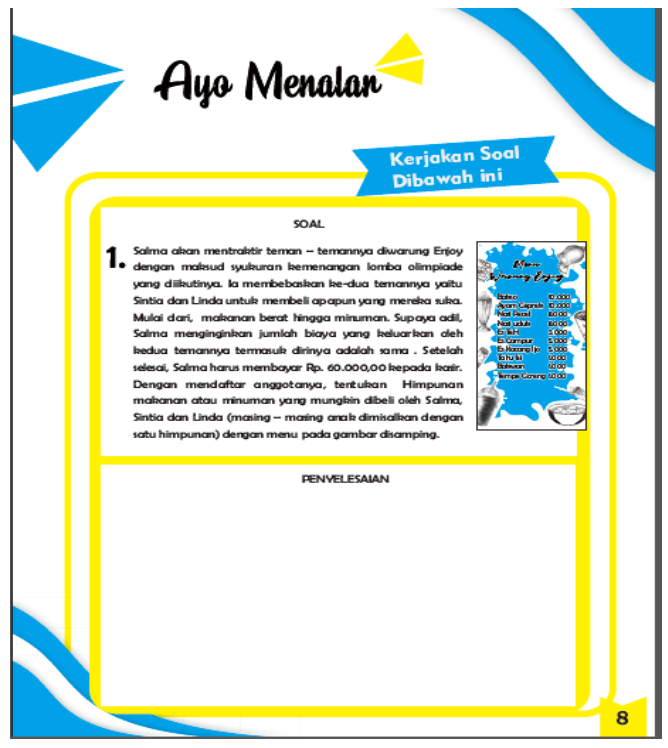

Gambar 4. Soal HOTS level menganalisis (C4).

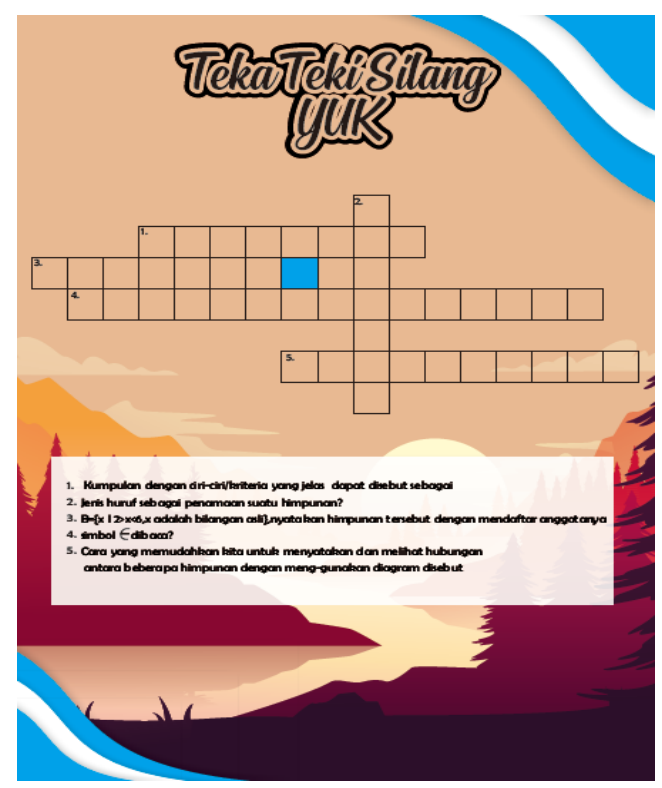

Gambar 5. Teka-teki silang materi himpunan.
Dalam LKPD ini juga terdapat halaman yang berbentuk teka-teki silang. Hal ini untuk menarik perhatian siswa. Pertanyaan yang disajikan berkaitan dengan materi yang sudah dipelajari sehingga dengan mengisi teka-teki silang tersebut dapat menguatkan kembali pengetahuan yang sudah diperoleh. Dapat dilihat pada Gambar 5.

\section{Tahap Pengembangan (Develop)}

Validasi dilakukan untuk memberi masukan terhadap produk awal yang dibuat. Ahli yang memvalidasi produk (validator) adalah 1 dosen dan 2 guru matematika SMP yang telah berpengalaman dalam mengajar, menyusun media pembelajaran yang inetraktif, dan memahami soal HOTS. Berikut hasil validasi yang dilakukan oleh ahli ditunjukkan pada Tabel 4.

Tabel 4. Hasil Angket Kevalidan LKPD HOTS

\begin{tabular}{|c|c|c|c|c|}
\hline No & Aspek & $\begin{array}{c}\text { Jumlah } \\
\text { Item }\end{array}$ & $\begin{array}{l}\text { Rata- } \\
\text { Rata }\end{array}$ & Ket. \\
\hline 1 & Isi & 7 & 3,28 & $\begin{array}{l}\text { Sangat } \\
\text { Valid }\end{array}$ \\
\hline 2 & Penyajian & 6 & 3,5 & $\begin{array}{l}\text { Sangat } \\
\text { Valid }\end{array}$ \\
\hline 3 & $\begin{array}{l}\text { Bermuatan } \\
\text { HOTS }\end{array}$ & 4 & 3 & Valid \\
\hline 4 & $\begin{array}{l}\text { Kelayakan } \\
\text { Kegrafikan }\end{array}$ & 12 & 2,8 & Valid \\
\hline 5 & $\begin{array}{l}\text { Bahasa } \\
\text { Kesimpulan }\end{array}$ & $\begin{array}{l}4 \\
\mathbf{3 3}\end{array}$ & $\begin{array}{l}3,08 \\
\mathbf{3 , 1 3}\end{array}$ & $\begin{array}{l}\text { Valid } \\
\text { Valid }\end{array}$ \\
\hline
\end{tabular}

Terdapat lima aspek yang dinilai dalam kevalidan LKPD yaitu isi, penyajian, bermuatan HOTS, kelayakan kegrafikan/tampilan, dan bahasa. Tabel 4 menggambarkan hasil rata-rata skor validasi dari masingmasing dosen dan guru pamong, dalam hal ini 1 dosen pendidikan matematika dan 2 guru matematika SMP. Untuk isi LKPD, diperoleh skor rata-rata validasi sebesar 3,28 artinya sangat valid. Penyajian memperoleh skor 3,5 (sangat 
valid), muatan HOTS dalam LKPD diperoleh skor 3 (valid), dan kelayakan kegrafikan/tampilan mendapat skor 2,8 (valid), Sedangkan, penggunaan bahasa didapat skor 3,08 (valid). Menurut para validator, ilustrasi sampul LKPD menggambarkan suasana sehari-hari dan letak judul, animasi, serta keterangan gambar tidak mengganggu siswa dalam memahami. Untuk hal tersebut, ketiganya memberikan penilaian sudah baik. Berdasarkan Tabel 4, diperoleh rerata akhir sebesar 3,13 yang artinya valid.

Terdapat beberapa masukan dari validator antara lain:

\section{a. Redaksi penulisan}

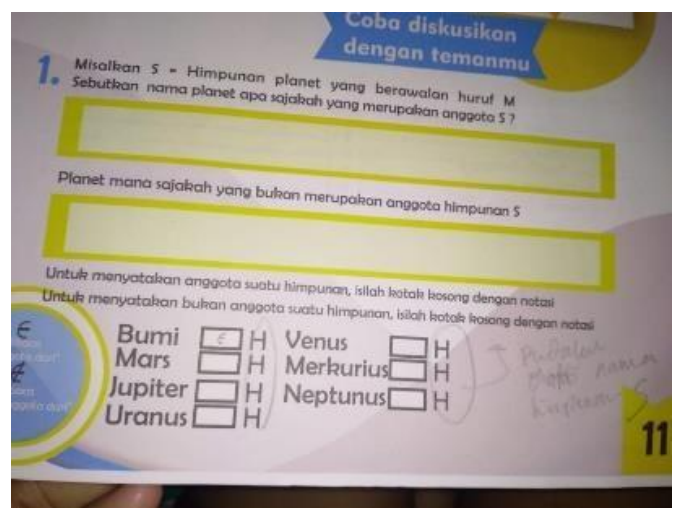

Gambar 6. Contoh kesalahan penulisan.

Pada Gambar 6, validator menyotroti tentang kesalahan penulisan himpunan $H$ seharusnya himpunan $S$. Kemudian, diperbaiki penamaan dengan mengganti menjadi himpunan $S$. Hasil perbaikan dapat dilihat pada Gambar 7.

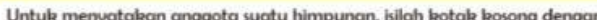

Untuk menyatakan bukan anggota suatu himpunan, kilah kotak kosong
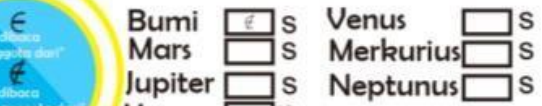

Neptunus $\square$ s

Gambar 7. Perbaikan kesalahan penulisan.

b. Redaksi tampilan

Validator memberikan saran bahwa dalam LKPD tidak ada peta konsep yang disajikan. Sebaiknya diberikan tampilan peta konsep agar siswa jelas mengenai sub materi apa saja yang dipelajari pada Himpunan. Perbaikan dapat dilihat pada Gambar 3. Selain itu, ruang jawaban dari soal terlalu luas, seharusnya bisa untuk dua nomor. Perbaikan hal tersebut dapat dilihat pada Gambar 8.

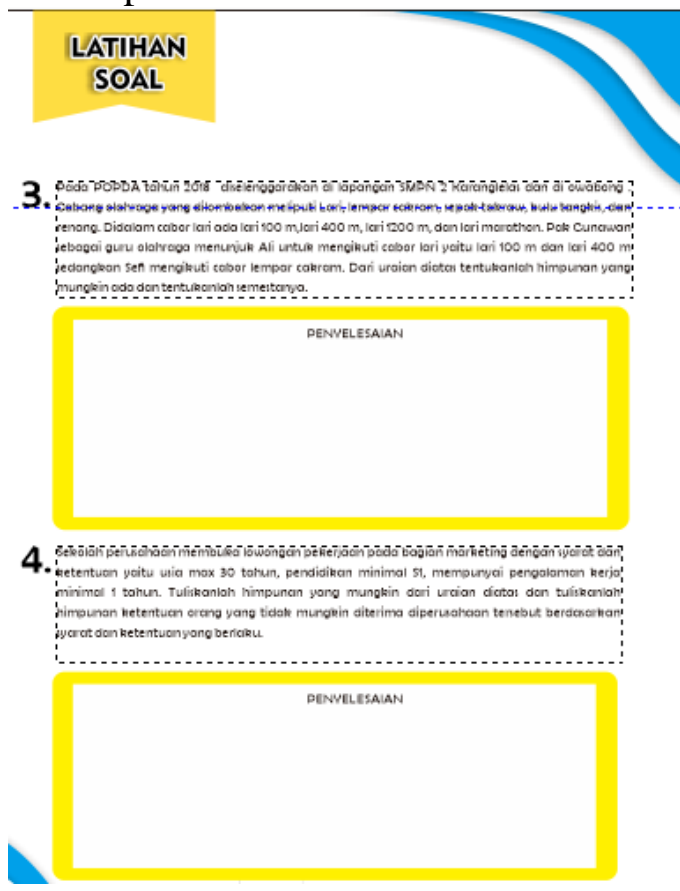

Gambar 8. Ruang jawaban LKPD.

4. Tahap Penyebaran (Disseminate) Uji kepraktisan dilakukan terbatas pada 9 siswa SMP kelas VIII. Siswa diambil berdasarkan pertimbangan guru dan yang memiliki respon positif terhadap pembelajaran dan LKPD tersebut. Selain itu, karena terbatas pada kondisi pandemi Covid19. Hasil angket kepraktisan LKPD disajikan dalam Tabel 5.

Berdasarkan Tabel 5, aspek yang dinilai dalam uji kepraktisan meliputi menarik, kreatif, kemudahan menggunakan LKPD, dan efisien. Pada aspek menarik, dari kesembilan siswa diperoleh skor rata-rata 3,01 (baik). Kemudian, dari aspek kreatif didapat 
DOI: https://doi.org/10.24127/ajpm.v9i4.3157

skor 3 (baik) dan skor 2,91 merepresentasikan kemudahan. Sedangkan, dari efisiensi diperoleh skor sebesar 3,13 (baik). Sehingga, LKPD berbasis HOTS pada materi himpunan dikatakan praktis untuk digunakan dalam pembelajaran bagi siswa SMP.

Tabel 5. Hasil angket kepraktisan LKPD HOTS.

\begin{tabular}{lllll}
\hline No & Aspek & $\begin{array}{l}\text { Jumlah } \\
\text { item }\end{array}$ & $\begin{array}{l}\text { Rata- } \\
\text { rata }\end{array}$ & Ket. \\
\hline 1 & Menarik & 3 & 3,01 & Baik \\
2 & Kreatif & 2 & 3 & Baik \\
3 & Kemudahan & 5 & 2,91 & Baik \\
4 & Efisien & 2 & 3,13 & Baik \\
Kesimpulan & $\mathbf{1 2}$ & $\mathbf{3 , 0 1}$ & Baik \\
\hline
\end{tabular}

Produk pengembangan pada penelitian ini menampilkan beberapa keunggulan dari produk LKPD yang sebelumnya digunakan siswa diantaranya meng-gunakan aplikasi Corel Draw untuk memberikan tampilan yang lebih menarik, menambahkan tampilan dalam bentuk teka teki silang yang beriisi pertanyaan terkait materi Himpunan sehingga dapat mengasah kemampuan siswa terkait materi, dan memberikan permasalahan untuk mengembangkan kemampuan berfikir tingkat tinggi siswa dalam bentuk contoh dan soal latihan. Akan tetapi, karena penggunaannya menggunakan aplikasi Corel Draw maka perlu belajar lebih mendalam kembali dan membutuhkan waktu yang cukup lama.

Penilaian kevalidan diantaranya meliputi isi, bahasa, dan muatan HOTS (Tabel 4). Hal tersebut relevan dengan penelitian (Ahmad, Prahmana, Kenedi, Helsa, Arianil, \& Zainil, 2017) bahwa validitas tergambar pada aspek konstruksi, bahasa, dan isi. Hasil kevalidan diperoleh skor rata-rata 3,13 yang berarti "Valid".
Sedangkan, penilaian kepraktisan LKPD diantaranya meliputi aspek tampilan menarik, kemudahan membaca/memahami (Tabel 5). Hal tersebut sesuai dengan penelitian (Khotimah \& Sari, 2020) bahwa kepraktisan terlihat dari kemudahan mengkases dan tampilan yang menarik. Hasil kepraktisan menunjukkan skor rata-rata 3,01 yang artinya "Praktis".

LKPD ini memberikan dampak bagi siswa dan guru antara lain siswa terbiasa dalam mengerjakan soal HOTS, memberikan motivasi belajar kepada siswa karena menemukan keterkaitan konsep matematika dengan kehidupan sehari-hari. Sedangkan, bagi guru memberikan dampak mengembangkan kreatifitas guru dalam memilih media pembelajaran yang lebih tepat sehingga proses belajar mengajar matematika dirasakan lebih menarik dan menyenangkan.

\section{KESIMPULAN DAN SARAN}

Pengembangan LKPD sebagai salah satu bahan ajar untuk membantu pemahaman siswa dengan mengambil ilustrasi sehari hari dilengkapi latihhn soal HOTS atau tingkat berfikir tingkat tinggi. Desain penelitian dimulai dengan analisis kebutuhan, desain, implementasi, validasi, revisi, ujicoba produk, produk akhir, dan kepraktisan. Tahapan-tahapan tersebut direalisasikan menjadi sebuah LKPD Matematika bermuatan HOTS pada materi himpunan kelas VIII SMP. Berdasarkan data penelitian, diperoleh hasil dari tahap validasi LKPD bermuatan HOTS yang dilakukan oleh 3 validator. Secara keseluruhan, uji validasi LKPD Matematika bermuatan HOTS pada materi himpunan kelas VIII SMP mencapai rata-rata 3,13 yang berarti valid. Hasil kepraktisan diperoleh skor rata-rata sebesar 3,01 yang artinya 
praktis. Dengan demikian, LKPD berbasis HOTS pada materi Himpunan dinyatakan valid dan praktis sehingga dapat diaplikasikan kepada siswa dalam kegiatan belajar didasarkan kepada hasil kevalidan dan kepraktisan. Untuk penelitian/ pengembangan berikutnya, dapat menambahkan kemampuan matematis yang akan diukur sebagai contoh kemampuan pemahaman konsep matematis.

\section{DAFTAR PUSTAKA}

Ahmad, S., Prahmana, R. C. I., Kenedi, A. K., Helsa, Y., Arianil, Y., \& Zainil, M. (2017). The instruments of higher order thinking skills. Journal of Physics: Conference Series, 943(1), 012053.

Apino, E., \& Retnawati, H. (2017). Developing instructional design to improve mathematical higher order thinking skills of students. Journal of Physics: Conference Series, 812(1), 012100.

Arikunto, S. (2010). Metode Penelitian. Jakarta: Rineka Cipta.

Dinni, H. N. (2018). HOTS (High Order Thinking Skills) dan kaitannya dengan kemampuan literasi matematika. In PRISMA (Prosiding Seminar Nasional Matematika) (pp. 170-176). Semarang: Universitas Negeri Semarang.

Fanani, M. Z. (2018). Strategi pengembangan soal hots pada kurikulum 2013. Edudeena: Journal of Islamic Religious Education, 2(1), 57-76.

Ichsan, I. Z., Sigit, D. V., Miarsyah, M., Ali, A., Arif, W. P., \& Prayitno, T. A. (2019). HOTS-AEP: Higher
Order Thinking Skills from Elementary to Master Students in Environmental Learning. European Journal of Educational Research, 8(4), 935-942.

Kurniati, D., Harimukti, R., \& Jamil, N. A. (2016). Kemampuan Berpikir Tingkat Tinggi Siswa SMP di Kabupaten Jember dalam Menyelesaikan Soal Berstandar PISA. Jurnal Penelitian Dan Evaluasi Pendidikan, 20(2), 142155.

Khotimah, R. P., \& Sari, M. C. P. (2020). Pengembangan Lembar Kerja Peserta Didik Berbasis Higher Order Thinking Skills (Hots) Menggunakan Konteks Lingkungan. Aksioma, 9(3), 761775.

Merta Dhewa, K., Rosidin, U., Abdurrahman, A., \& Suyatna, A. (2017). The development of Higher Order Thinking Skill (Hots) instrument assessment in physics study. IOSR Journal of Research \& Method in Education (IOSRJRME), 7(1), 26-32.

Mulyaningsih, I., \& Itaristanti, I. (2018). Pembelajaran Bermuatan HOTS (Higher Order Thinking Skill) di Jurusan Tadris Bahasa Indonesia. Indonesian Language Education and Literature, 4(1), 113-128.

Noprinda, C. T., \& Soleh, S. M. (2019). Pengembangan Lembar Kerja Peserta Didik (LKPD) Berbasis Higher Order Thinking Skill (HOTS). Indonesian Journal of Science and Mathematics Education, 2(2), 168-176.

Pratiwi, W. (2018). (2018, November). Pengembangan bahan ajar bermuatan High Order Thinking 
DOI: https://doi.org/10.24127/ajpm.v9i4.3157

Skill (HOTS) pada pembelajaran tema persatuan dalam perbedaan. In Seminar Nasional Universitas Muhammadiyah Semarang (pp. 531-538). Semarang: Universitas Muhammadiyah Semarang.

Rooney, C. (2012). How am I using inquiry-based learning to improve my practice and to encourage higher order thinking among my students of mathematics? Educational Journal of Living Theories, 5(2), 100-127.

Tanujaya, B., Mumu, J., \& Margono, G. (2017). The Relationship between Higher Order Thinking Skills and Academic Performance of Student in Mathematics Instruction. International Education Studies, 10(11), 78-85.

Tanujaya, B. (2016). Development of an Instrument to Measure Higher Order Thinking Skills in Senior High School Mathematics Instruction. Journal of Education and Practice, 7(21), 144-148.
Thiagarajan, S.S., S., \& Semmel. (1974). Instructional Development forTraining Teacher of Exceptional Children a Sourcebook. Bloomington: Center for innovation on Teaching the Handicaped.

Trianto. (2010). Mengembangkan Model Pembelajaran Tematik. Jakarta: PT Prestasi Pustaka.

Winarni, W. (2019). Peningkatan Kemampuan Berpikir Tingkat Tinggi Menggunakan Huruf Kapital Melalui Penerapan Model PJBL di SD IT Izzatul Islam Getasan. Manajemen Pendidikan, 14(1), 18-24. 